\title{
PERBANDINGAN SERAT ABAKA (MUSA TEXTILLIS NEE) DAN SERAT SABUT KELAPA SEBAGAI BAHAN TAMBAH TERHADAP CAMPURAN BETON

\author{
Lina Halim Rachman ${ }^{1 *}$,SSN. Banjarsanti, ${ }^{2}$, Yudi Pranoto ${ }^{3}$ \\ 123, Jurusan Teknik Sipil, Politeknik Negeri Samarinda \\ Jl. Cipto Mangunkusumo, Samarinda Kalimantan Timur \\ *E-mail: linahalim0@gmail.com
}

\begin{abstract}
Abstrak
Pemilihan Serat Abaka dan Serat Sabut Kelapa sebagai bahan tambah dalam campuran beton dengan memanfaatkan batang pohon pisang dan limbah buah kelapa yang kurang dimanfaatkan. Tujuan penelitian ini adalah untuk menganalisi pengaruh serat abaka dan serat sabut kelapa terhadap kuat tekan dan kuat lentur beton. Penelitian ini menggunakan bahan tambah Serat Abaka dan Serat Sabut Kelapa dengan kadar 0,4\%, 0,5\% dan $0,6 \%$. Penelitian ini dimulai dari kajian pustaka, pengadaan material, pengujian material, analisis data, membuat mix design, pembuatan benda uji, pengujian kuat tekan dan kuat lentur serta analisa hasil pengujian. Dari hasil penelitian didapatkan, nilai kuat tekan optimum pada beton Serat Abaka dengan persentase serat $0,5 \%$ dengan nilai kuat tekan karakteristik sebesar 26,29 MPa sedangkan pada serat sabut kelapa nilai kuat tekan maksimum dengan persentase serat $0,6 \%$ dengan kuat tekan karakteristik 25,07 MPa. Kuat lentur beton Serat Abaka maksimum 3,75 MPa, dan pada beton Serat Sabut Kelapa 3,07 MPa.
\end{abstract}

Kata kunci: Serat abaka, serat sabut kelapa, kuat tekan, kuat lentur.

\section{PENDAHULUAN}

Beton merupakan salah satu material konstruksi yang digunakan untuk membuat perkerasan jalan, struktur bangunan, fondasi, jalan, jembatan, struktur parkiran, dasar untuk pagar/gerbang, dan semen dalam bata atau tembok blok, drainase dan lain-lain. Berdasarkan kuat tekannya beton dibagi menjadi tiga klasifikasi, yaitu beton normal dengan kekuatan tekan kurang dari $50 \mathrm{Mpa}$, beton kinerja tinggi dengan kekuatan tekan antara 50 hingga $90 \mathrm{Mpa}$, beton kinerja sangat tinggi dengan kekuatan tekan lebih dari $90 \mathrm{Mpa}$ (Hani, 2018). Untuk mendapatkan sifat - sifat beton yang lebih baik, banyak hal dapat dilakukan. Mulai dari peningkatan mutu material beton sampai dengan menambahkan zat adiktif. Zat adiktif dapat berupa cairan maupun serat.

Dalam perkembangannya beton mengalami perubahan variasi, salah satunya adalah beton serat. Menurut (Committee, (1982)) yang dimaksud dengan beton serat adalah struktur yang tersusun dari bahan semen, agregat halus, agregat kasar, dan sejumlah kecil serat sebagai bahan tambah. Penambahan serat dalam proporsi tertentu kemungkinan dapat mempengaruhi perilaku struktur beton secara keseluruhan (Zulkifly, 2013). Dari berbagai serat yang ada, penulis memilih serat abaka dan serat sabut kelapa. Kedua serat tersebut digunakan sebagai bahan tambah dengan memanfaatkan batang pohon pisang abaka dan limbah buah kelapa yang kurang dimanfaatkan yang diharapkan dapat memperbaiki sifat beton.

Pisang Abaka memiliki keuntungan di antara serat pisang pada umumnya karena memiliki karakteristik mekanik di atas serat pisang pada umumnya. Berbeda dengan kebanyakan jenis pisang lainnya, Pisang Abaka justru dimanfaatkan batangnya. Pisang Abaka merupakan salah satu tanaman penghasil serat bukan kayu (non wood) yang memiliki serat panjang. Serat abaka memiliki kekuatan tarik dan kekuatan lentur yang baik dan tahan terhadap kebusukan (Hintermann, 2005).

Sabut kelapa merupakan bagian terbesar dari buah kelapa yaitu sekitar $35 \%$ dari bobotnya (Elhusna, 2011). Dabut biasanya dibuat sebagai limbah yang hanya ditumpuk di bawah tegakan tanaman kelapa lalu dibiarkan membusuk atau kering pemanfaatannya paling banyak hanyalah untuk kayu bakar. Secara tradisional, masyarakat mengolah sabut untuk dijadikan tali dan dianyam menjadi keset (Putra, 2019). Sabut kelapa merupakan limbah yang mudah didapat pada daerah di sepanjang pesisir seperti kebanyakan wilayah Indonesia. Indonesia merupakan negara penghasil kelapa yang utama di dunia dengan luas perkebunan kelapa mencapai 3,76 juta $\mathrm{Ha}$ dan total produksi sebanyak 14 milyar butir kelapa (Anonim, 2000). 
Pada penelitian ini menggunakan panjang serat $2,2 \mathrm{~cm}$ dengan persentase $0,4 \%$, $0,5 \%$ dan $0,6 \%$. Hal tersebut mengacu dari hasil penelitian sebelumnya oleh (Purnama, 2011) dengan hasil penelitiannya penambahan variasi panjang serat abaka optimum berkisar 2 $\mathrm{cm}-2,3 \mathrm{~cm}$ dan (Utomo, 2011) dengan hasil penelitiannya Penambahan kadar serat optimum yang menghasilkan kuat tekan maksimum untuk panjang serat $10 \mathrm{~mm}, 20 \mathrm{~mm}$ dan $30 \mathrm{~mm}$. Untuk panjang serat $10 \mathrm{~mm}$ penambahan kadar serat optimumnya adalah $0,49 \%$, untuk panjang serat $20 \mathrm{~mm}$ penambahan kadar serat optimumnya adalah $0,5 \%$, sedangkan untuk panjang serat $30 \mathrm{~mm}$ penambahan kadar serat optimumnya adalah $0,48 \%$ dan panjang serat optimum yang dipakai agar mendapatkan kuat tekan yang maksimum untuk variasi penambahan kadar serat $0,25 \%$, $0,5 \%, 0,75 \%$ dan $1 \%$. Untuk variasi serat $0,25 \%$ didapat panjang optimumnya adalah $20,72 \mathrm{~mm}$, untuk variasi serat $0,5 \%$ panjang optimumnya adalah $26,25 \mathrm{~mm}$, untuk variasi serat $0,75 \%$ panjang serat optimumnya adalah $29,5 \mathrm{~mm}$ dan untuk variasi serat $1 \%$ panjang optimumnya adalah $22 \mathrm{~mm}$. Untuk kuat tekannya menunjukkan bahwa penambahan serat abaka akan menaikan kuat tekan.

\section{METODE PENELITIAN}

Penelitian ini dilakukan di Laboratorium Bahan Jurusan Teknik Sipil Politeknik Negeri Samarinda. Metode eksperimen pada penelitian ini dilakukan dengan cara mencari perbandingan bahan tambah terhadap beton menggunakan serat abaka dan serat sabut kelapa dengan variasi yang telah ditentukan. Kemudian beton dengan bahan tambah tersebut akan diuji dengan pengujian kuat tekan beton dan kuat lentur beton.

Dalam penyusunan penelitian terdapat tahapan yang dilakukan yang diawali dengan kajian pustaka, pengadaan material, pengujian material, perencanaan campuran beton (mix design), perawatan benda uji (curing), pengujian kuat tekan dan kuat lentur beton, kemudian analisa data.

Standar pengujian kuat tekan beton yang dipakai adalah SNI 03-1974-1990. Berikut merupakan rumus yang digunakan pada pengujian kuat tekan beton: $\mathrm{fc}^{\prime}=\frac{P}{A}$.......

Keterangan :

$\mathrm{fc}^{\prime}=$ Kuat tekan beton $\left(\mathrm{kg} / \mathrm{cm}^{2}\right)$

$\mathrm{P}=$ beban maksimum $(\mathrm{kg})$

$A=$ luas penampang benda uji $\left(\mathrm{cm}^{2}\right)$

Adapun rumus yang digunakan untuk pengujian kuat lentur menurut SNI 4431:2011 adalah sebagai berikut:

a. Untuk pengujian dimana bidang patah terletak di daerah pusat (daerah 1/3 jarak titik perletakan bagian tengah) :

$\sigma 1=\frac{P . L}{b . h^{2}}$

b. Untuk pengujian dimana patahnya benda uji ada di luar pusat (daerah 1/3 jarak titik perletakan bagian tengah), dan jarak antara titik pusat dan titik patah kurang dari $5 \%$ dari titik antara titik perletakan:

$\sigma 1=\frac{P \cdot a}{b . h^{2}}$

Keterangan :

$\sigma \mathrm{l}=$ kuat lentur benda uji (MPa)

$\mathrm{P}=$ beban tertinggi yang terbaca pada mesin uji (pembacaan dalam ton sampai 3 angka di belakang koma)

$\mathrm{L}=$ jarak (bentang) antara dua garis perletakan $(\mathrm{mm})$

$b=$ lebar tampang lintang patah arah horizontal $(\mathrm{mm})$

$\mathrm{h}=$ lebar tampang lintang patah arah vertikal $(\mathrm{mm})$

$a=$ jarak rata-rata antara tampang lintang patah dan tumpuan luar yang terdekat, diukur pada 4 tempat pada sudut dari bentang (mm)

\section{HASIL DAN PEMBAHASAN}

Dari penelitian yang telah diakukan didapatkan hasil berupa data-data kuat tekan dan kuat lentur.

\section{HASIL}

Penelitian ini dilakukan di Laboratorium Bahan Tenknik Sipil Politeknik Negeri Samarinda. Guna memperoleh hasil penelitian yang sesuai dengan apa yang diharapkan, diperlukan proses perencanaan dan pelaksanan pekerjaan yang baik dan benar.

Tabel 1. Hasil pengujian karakteristik semen pcc merk tonasa

\begin{tabular}{ccc}
\hline No. & Karakteristik & Hasil \\
\hline 1. & Berat Jenis Semen & 3,012 \\
2. & Konsistensi Normal & $24,1 \%$ \\
& Setting Time & \\
3. & Pengikatan Awal & 47,3 Menit \\
& Pengikatan Akhir & 135 Menit \\
\hline
\end{tabular}




\section{Lina Halim Rachman ${ }^{1^{*}}$, SSN. Banjarsanti ${ }^{2}$, Yudi Pranoto ${ }^{3}$}

Berdasarkan hasil pengujian yang telah dilakukan terhadap semen PCC merk Tonasa, menunjukkan bahwa semen tersebut memenuhi Standar Nasional Indonesia (SNI) yang telah ditentukan.

Tabel 2. Hasil pengujian karakteristik agregat halus (pasir palu)

\begin{tabular}{ccc}
\hline No. & Karakteristik & Hasil \\
\hline 1. & Bobot Isi & $1,34 \mathrm{gr} / \mathrm{cm} 3$ \\
2. & Berat Jenis & 2,51 \\
3. & Penyerapan & $0,60 \%$ \\
4. & Kadar Air & $1,88 \%$ \\
5. & Kadar Lumpur & $3,09 \%$ \\
\hline
\end{tabular}

Tabel 4.3 Hasil pengujian karakteristik agregat kasar palu (batu pecah $1 / 2$ )

\begin{tabular}{ccc}
\hline No. & Karakteristik & Hasil \\
\hline 1. & Bobot Isi & $1,59 \mathrm{gr} / \mathrm{cm} 3$ \\
2. & Berat Jenis & 2,63 \\
3. & Penyerapan & $0,85 \%$ \\
4. & Kadar Air & $0,60 \%$ \\
5. & Abrasi & $23,21 \%$ \\
6. & Kadar Lumpur & $0,42 \%$ \\
\hline
\end{tabular}

Berdasarkan hasil pengujian yang telah dilakukan terhadap agregat halus (Pasir Palu) dan Batu Pecah Palu 1/2, menunjukkan bahwa kedua bahan tersebut memenuhi Standar Nasional Indonesia (SNI) yang telah ditentukan.

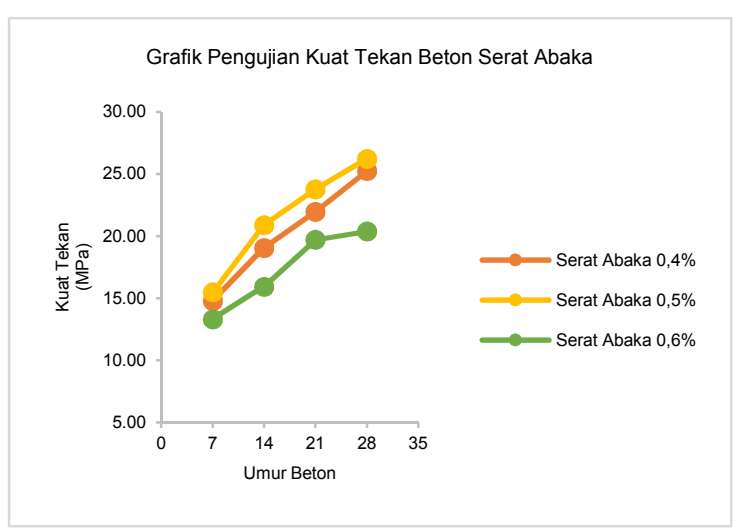

Gambar 1. Grafik kuat tekan beton variasi serat abaka berdasarkan umur beton

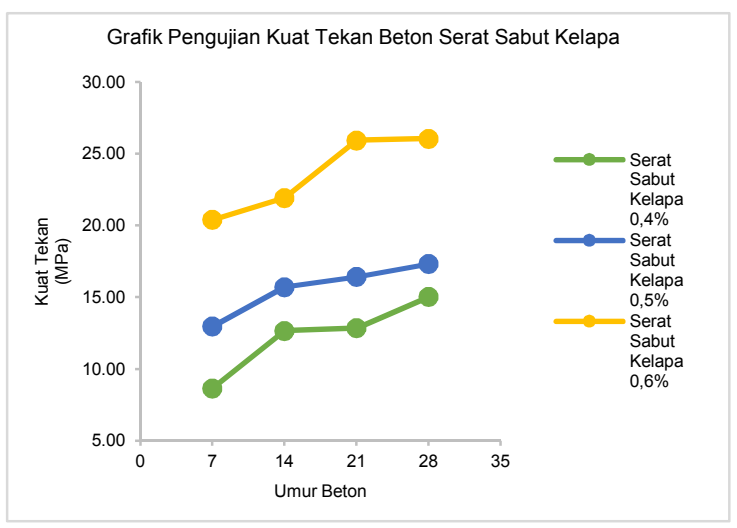

Gambar 4.14 Grafik kuat tekan beton variasi serat sabut kelapa berdasarkan umur beton

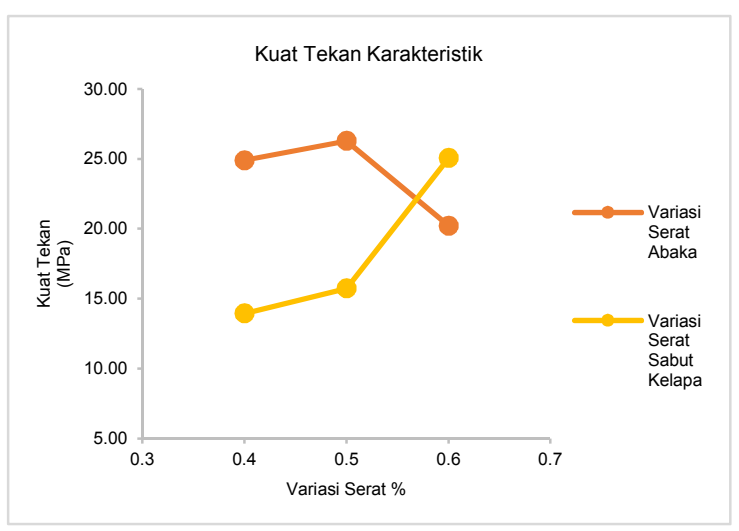

Gambar 3. Grafik hubungan kuat tekan karakteristik beton serat abaka dan serat sabut kelapa

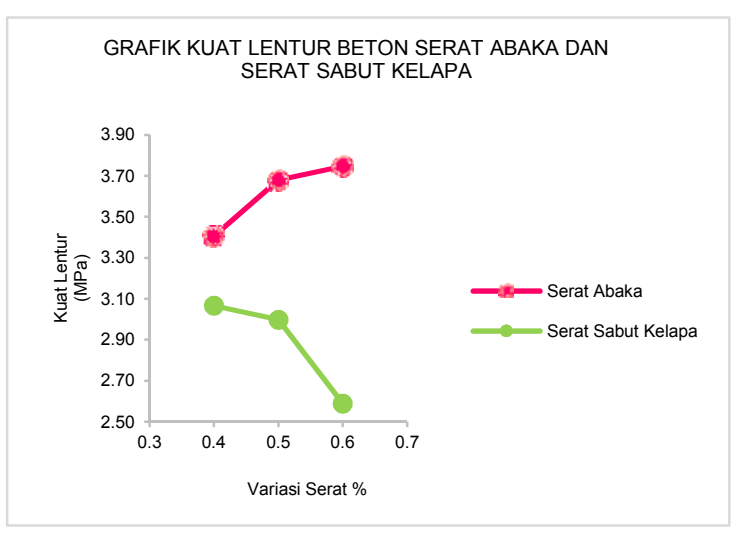

Gambar 4. Grafik perbandingan kuat lentur beton serat abaka dan serat sabut kelapa

\section{PEMBAHASAN}

Dari penelitian yang telah diakukan 
didapatkan hasil berupa data-data dan dibuat grafik dengan bahasan sebagai berikut.

Berdasarkan Gambar 4.1 diketahui beton dengan variasi Serat Abaka 0,4\% dan $0,5 \%$ mengalami peningkatan nilai kuat tekan beton, tetapi mengalami penurunan nilai kuat tekan pada persentase $0,6 \%$. Sedangkan di lihat dari Gambar 4.2 pada beton variasi Serat Sabut Kelapa menunjukkan nilai kuat tekan beton mengalami peningkatan.

Berdasarkan Gambar 3 diatas dapat diketahui bahwa kadar Serat Abaka optimum adalah $0,5 \%$ dengan nilai kuat tekan karakteristik sebesar 26,29 MPa, meningkat $5,5 \%$ dari nilai kuat tekan beton variasi $0,4 \%$ Serat Abaka, dan penurunan terjadi pada beton kadar serat $0,6 \%$ sebesar $18,8 \%$ dari beton kadar serat $0,4 \%$ dan sebesar $23,04 \%$ terhadap beton kadar serat $0,5 \%$. Nilai kuat tekan karakteristik pada variasi Serat Sabut Kelapa mengalami peningkatan, namun pada kadar $0,4 \%$ dan $0,5 \%$ nilai kuat tekan lebih rendah dari nilai kuat tekan rencana. Kadar Serat Sabut Kelapa yang optimum adalah 0,6\% dengan nilai kuat tekan karakteristik sebesar $25,07 \mathrm{MPa}$, meningkat $79,6 \%$ dari nilai kuat tekan beton variasi $0,4 \%$ Serat Sabut Kelapa, $59.28 \%$ dari nilai kuat tekan beton variasi $0,5 \%$ Serat Sabut Kelapa.

Berdasarkan Gambar 4 diketahui bahwa beton dengan variasi Serat Abaka mengalami peningkatan seiring penambahan kadar serat dengan nilai kuat lentur berturutturut 3,41 $\mathrm{MPa}, 3,68 \mathrm{MPa}$ dan 3,75 MPa. Sedangkan beton dengan variasi Serat Sabut Kelapa mengalami penurunan nilai kuat lentur seiring penambahan kadar serat, dengan hasil nilai kuat lentur berturut-turut sebesar 3,07 $\mathrm{MPa}, 3,00 \mathrm{MPa}$ dan 2,59 MPa.

\section{PENUTUP}

Dari hasil pengujian yang telah dilakukan pada beton dengan bahan tambah Serat Abaka dan Serat Sabut Kelapa dengan masingmasing persentase $0,4 \%, 0,5 \%$ dan $0,6 \%$, disimpulkan bahwa penambahan Serat Abaka pada campuran beton dapat mempengaruhi nilai kuat tekan beton, dimana kuat tekan maksimum dihasilkan pada serat kadar 0,5\%. dan penambahan Serat Abaka memicu peningkatan nilai kuat lentur seiring penambahan kadar serat, pada presentase $0,6 \%$. Penambahan Serat Sabut Kelapa pada campuran beton dapat mempengaruhi nilai kuat tekan beton, dimana seiring penambahan kadar serat menghasilkan kuat tekan yang maksimal. Sedangkan terhadap kuat lentur, semakin besar kadar serat yang ditambahkan membuat kuat lentur menurun

Dari kesimpulan disarankan penelitian selanjutnya dapat menggunakan variasi serat Abaka dengan persentase yang lebih untuk pengujian kuat lentur dan persentase serat yang lebih untuk pengujian kuat tekan.

\section{UCAPAN TERIMAKASIH}

Penulis mengucapkan terima kasih sebesar-besarnya kepada Laboratorium Politeknik Negeri Samarinda yang telah memfasilitasi tempat dan peralatan guna melaksanakan penelitian ini.

\section{DAFTAR PUSTAKA}

Anonim, 2000. Pemanfaatan Kelapa di Indonesia. Jakarta, Direktorat Kredit, Bpr dan UMKM.

Committee, A., (1982). State of the Art Report in Fiber Reinforced Concrete. s.I.:Scientific Research An Academic Publisher.

Elhusna, 2011. Pengaruh Serat Sabut Kelapa Terhadap Kuat Lentur Beton Dengan Faktor Air Semen 0,5. Jurnal, Volume 3, p. 39.

Hani, S., 2018. Pengaruh Campuran Serat Pisang Terhadap Beton. Jurnal Education Building, Volume 4 Nomor 1, p. 41.

Hintermann, M., 2005. Automotive exterior parts from natural fibres. s.I., Riko.

Purnama, D., 2011. Pengaruh Penambahan Serat Abaka Terhadap Kuat Lentur Geopolymer Mortar Berbahan Dasar Abu Terbang. Surakarta: Universitas Sebelas Maret.

Putra, 2019. Analisa Perbandingan Limbah Serat Serabut Kelapa Dan Serat Purun Terhadap Kuat Tekan Dan Kuat Tarik Belah Beton Fc' 18. Palembang: Universitas Muhammadiyah Palembang.

Putra, A. M., 2019. Analisa Perbandingan Limbah Serat Serabut Kelapa dan Serat Purun Terhadap Kuat Tekan dan Kuat Tarik Belah Beton $f F C^{\prime}$ 18. Palembang: Universitas Muhammadiyah Palembang.

Standar Nasional Indonesia 03-1974-1990. Metode Pengujian Kuat Tekan Beton. 
Standar Nasional Indonesia 4431:2011.

Metode Pengujian Kuat Lentur Beton.

Utomo, P., 2011. Pengaruh Penambahan Serat Abaka Terhadap Slump Flow dan Kuat Tekan Fly Ash-Based Geopolymer Mortar. Surakarta: Universitas Sebelas Maret.

Zulkifly, 2013. Pengaruh Penambahan Serat Sabut Kelapa Terhadap Kuat Tekan Beton Pada Beton Normal. Jurnal Stabilita, Volume Vol. 1 No. 2 April 2013, p. 121 